\title{
Analysis of Engine and Propeller Selection for Unmanned Aircraft LSU-05 NG
}

\author{
Novita Atmasari ${ }^{1, *}$, Muksin $^{2}$, Hartono $^{3}$, Ryan Hidayat ${ }^{4}$ \\ ${ }^{1,2,3,4}$ Pusat Teknologi Penerbangan , Lembaga Penerbangan dan Antariksa Nasional \\ Email Korespondensi: "novita.atmasari@lapan.go.id
}

Received: 12 Oktober 2020; Accepted : 28 Oktober 2020; Published : 1 November 2020

\begin{abstract}
ABSTRAK
Penelitian ini berfokus pada analisis pemilihan mesin dan propeler untuk sistem propulsi pesawat LSU-05 NG dengan melakukan kalkulasi kebutuhan daya dorong pesawat. Kebutuhan daya dorong dievaluasi pada dua kondisi pembebanan yaitu pembebanan berat (heavy loading) dengan memperhatikan kecepatan take-off minimum dan pembebanan ringan (light loading) dengan memperhatikan kecepatan terbang jelajah (cruise) maksimum. Selanjutnya dari lima rekomendasi mesin yang tersedia, dilakukan analisa efisiensi putaran propeler, gaya dorong yang dihasilkan, serta berat mesin yang memenuhi syarat DRO (Design Requirment and Objective) pesawat. Hasil penelitian ini memberikan rekomendasi penggunaan mesin yang memiliki daya minimal $16.5 \mathrm{hp}$ dengan kandidat utama mesin DLE 170 dan propeler ukuran 32x10 sebagai sistem propulsi LSU-05 NG.
\end{abstract}

Kata Kunci : LSU-05 NG, mesin, propeler, propulsi

\section{ABSTRACT}

This research focuses on analyzing the selection of engine and propeller for the propulsion system of LSU-05 NG by calculating the aircraft power needs. The aircraft power is evaluated in two loading conditions, namely heavy loading with regard to minimum take-off speed and light loading with regard to maximum cruise speed. Furthermore, from the five engine recommendations available, propeller rotation efficiency, thrust generated, and engine weight that meets the aircraft DRO (Design Requirment and Objective) are analyzed. The results of this research provide recommendations for using an engine with a minimum power of $16.5 \mathrm{hp}$ with the main candidate is DLE 170 and a $32 x 10$ size propeller as the LSU-05 NG propulsion system.

Keywords: LSU-05 NG, engine, propeller, propulsion

\section{PENGANTAR}

Lapan Surveillance UAV (LSU)-05 NG merupakan varian generasi baru pengembangan dari Pesawat Terbang Tanpa Awak (PTTA) LSU-05. LSU-05 NG memiliki dua misi utama yakni untuk pemantauan dan pemotretan udara, baik untuk lingkungan udara diatas laut, dekat laut, maupun di darat. PTTA ini memiliki estimasi awal MTOW sebesar $85 \mathrm{~kg}$ dengan kemampuan terbang sampai 2,5 jam dan kecepatan operasional sebesar $30 \mathrm{~m} / \mathrm{s}$. LSU-05 NG mampu terbang dengan operasional payload sejauh 400 $\mathrm{km}$ selama 5 jam dan kecepatan maksimum sebesar $40 \mathrm{~m} / \mathrm{s}$ [1]. PTTA generasi terbaru ini perlu dilakukan pengembangan dan perbaikan dari segi desain aerodinamika, struktur, maupun sistem propulsinya agar mempunyai performa terbang yang lebih baik dari generasi pertama untuk melakukan misi terbangnya. Salah satu fokus utama pengembangan LSU-05 NG ini adalah pemilihan sistem propulsi yang akan diintegrasikan, dalam hal ini adalah pemilihan kesesuaian mesin dan propeler yang mampu memenuhi kebutuhan operasi terbang pesawat dengan efisien. Oleh karena itu, penelitian yang berfokus pada analisis pemilihan mesin dan propeler pesawat LSU-05 NG ini dilakukan untuk menunjang dan mendukung pengembangan sistem propulsi yang sesuai untuk pesawat LSU-05 NG.

Penelitian serupa mengenai pemilihan mesin dan propeler telah dilakukan oleh Anggraeni, dkk pada tahun 2014 menggunakan metode analitik dan eksperimental atau pengujian. Metode analitik yang digunakan adalah melalui perhitungan kebutuhan daya pesawat saat terbang jelajah (cruise) dan mendaki (climb). Selanjutnya metode eksperimental atau pengujian dilakukan pada test bench, berdasarkan daya dorong statik mesin dan propeler. Kemudian pemilihan mesin dan propeler dilakukan dengan menganalisis perbandingan antara hasil perhitungan dan pengujian [2]. Pada tahun yang sama, Balachandran, dkk juga melakukan penelitian terkait pemilihan dan analisis propulsi untuk pesawat tanpa awak. Dalam penelitiannya, propeler dipilih berdasarkan efisiensi daya dorong yang dihasilkan. Selanjutnya kriteria utama pemilihan propeler didasarkan pada karakteristik kebisingan, downwash, torsi, dan rpm [3].

Pada tahun 2015, Dinç juga melakukan penelitian serupa menggunakan metode analitis untuk suatu UAV dengan mesin turboprop. Dalam penelitiannya, parameter profil misi seperti ketinggian dan kecepatan 
menjadi salah satu kunci untuk memilih jenis mesin. Beberapa parameter mesin yaitu rasio tekanan kompresor dan temperature masuk turbin berpengaruh langsung terhadap konsumsi bahan bakar spesifik mesin (SFC), yang selanjutnya berpengaruh pada dimensi umum dan berat kotor pesawat [4]. Kemudian pada tahun 2018, Setyadewi dan Nugroho melakukan penelitian serupa yaitu pemilihan propeler untuk pesawat LSU-03. Dalam penelitiannya, dilakukan uji statik propulsi pesawat LSU-03 di laboratorium propulsi guna mengetahui kemampuan mesin dan pemilihan propeler yang tepat untuk menghasilkan gaya dorong yang sesuai dengan pesawat dan misi yang akan dilakukan. Propeler yang diuji adalah jenis 3 bilah berukuran $20 \mathrm{x}$ 10 dan 21 x 14. Adapun sensor yang digunakan untuk mengukur gaya dorong berupa load cell tipe $S$ beam berkapasitas $100 \mathrm{KgF}$. Hasil uji mesin yang diperoleh kemudian divalidasi dengan membandingkan hasil perhitungan menggunakan aplikasi kalkulator propeler [5].

Selanjutnya penelitian mengenai analisis pemilihan mesin dan propeler untuk PTTA LSU-05 NG ini dilakukan dengan mengacu dan menggabungkan metode-metode yang digunakan pada penelitian sebelumnya yaitu penelitian yang telah dilakukan oleh Anggraeni dkk (2014), Balachandran dkk (2014), serta Setyadewi dan Nugroho (2018). Dalam penelitian ini, pemilihan mesin beserta propeler guna memenuhi kebutuhan operasi pesawat dilakukan dengan menggunakan metode analisa perhitungan teoritis. Pemilihan mesin dan propeler diawali dengan penghitungan tenaga mesin pada dua kondisi pembebanan yaitu pembebanan ringan untuk terbang jelajah dan pembebanan berat untuk lepas landas [6]. Setelah diperoleh beberapa kandidat mesin yang akan dipilih, tahap selanjutnya adalah matching propeller yaitu penentuan propeler yang sesuai dengan kandidat mesin tersebut. Analisa pemilihan propeler dilakukan dengan menggunakan aplikasi statistik Prop Power Calculator [7]. Propeler referensi awal yang digunakan dalam perhitungan kebutuhan daya adalah propeler dua bilah berukuran $30 \times 12,32 \times 10$, dan $32 \times 12$. Pada tahap matching propeller, tiga referensi propeler tersebut dibandingkan untuk memprediksi daya dorong yang dihasilkan. Selanjutnya proses seleksi tahap terakhir adalah memilih dan menentukan mesin dan propeler menggunakan studi persyaratan gaya dorong, efisiensi putaran propeler, serta berat mesin yang disesuaikan dengan kebutuhan muatan pesawat. Hasil penelitian ini memberikan rekomendasi penggunaan mesin dengan daya minimal $16.5 \mathrm{hp}$ dan propeler ukuran 32x10 sebagai sistem propulsi PTTA LSU-05 NG.

\section{METODE PENELITIAN}

Proses perhitungan daya poros mesin memerlukan beberapa parameter yang diperoleh dari persyaratan desain pesawat terbang, dalam hal ini adalah konfigurasi data LSU-05 NG. Data atau parameter tersebut berupa maximum take-off weight (MTOW) pesawat, kecepatan jelajah maksimum pesawat, dimensi propeler, dan rasio weight to power (power loading) pesawat. Rasio weight to power merupakan perbandingan tenaga mesin untuk penerbangan dengan berat pesawat tertentu. Rasio weight to power dipilih dari matching chart yang telah ditentukan sebelumnya dan terkait dengan persyaratan dan tujuan desain (DRO). Parameter yang dibutuhkan dalam perhitungan kebutuhan daya pesawat LSU-05 NG ditunjukkan pada Tabel 1 [8].

Tabel 1. Konfigurasi data LSU-05 NG

\begin{tabular}{lcc}
\hline Parameter & Nilai & Satuan SI \\
\hline Wing Loading & 261,1 & $\mathrm{~N} / \mathrm{m}^{2}$ \\
Power Loading & 85,8 & $\mathrm{~N} / \mathrm{hp}$ \\
MTOW & 85 & $\mathrm{~kg}$ \\
$V_{c r}$ & 40 & $\mathrm{~m} / \mathrm{s}$ \\
\hline
\end{tabular}

Rasio weight to power merupakan acuan utama dalam pemilihan mesin. Pada perhitungan daya mesin, rasio weight to power merupakan variabel penuntun untuk mengetahui apakah daya mesin untuk terbang mencukupi atau tidak. Oleh krena itu diperlukan satu rasio lagi untuk input data perhitungan, yaitu rasio thrust to weight atau koefisien dorong. Rasio thrust to weight atau koefisien dorong adalah rasio daya dorong maksimum yang dihasilkan oleh mesin pesawat dengan berat total pesawat. Pada umumnya rasio thrust to weight ditentukan dari rule of thumb atau kesepakatan antara desainer pesawat. Referensi ini berasal dari desain pesawat sebelumnya. Referensi tersebut menyatakan bahwa daya dorong statis yang cukup mendapatkan kemampuan pesawat untuk menjelajah dan mendaki setidaknya sepertiga dari total berat pesawat [2], [5], [6]. Koefisien dorong tanpa dimensi dapat ditentukan dengan persamaan (1).

$$
T c \equiv \frac{T}{\frac{1}{2} \rho V^{2} \pi R^{2}}
$$

Selain koefisien dorong, juga diperlukan adanya perhitungan efisiensi viskos dan invised. Efisiensi viskos tidak banyak bervariasi dan sering dianggap konstan sementara untuk efisiensi invised mempunyai batasan yang ditentukan dengan persamaan (2) [6]. 


$$
\eta_{i} \leq \frac{2}{1+\sqrt{1+T c}}
$$

Berdasarkan persamaan (1) dan persamaan (2), baik koefisien dorong maupun efisiensi invised sangat bergantung pada gaya dorong dan kecepatan terbang, serta ukuran propeler. Setelah dilakukan perhitungan koefisien dorong, proses selanjutnya adalah melakukan perhitungan daya poros mesin yang dibutuhkan oleh propeler pada dua kondisi pembebanan yaitu kondisi pembebanan ringan (light loading) dan pembebanan berat (heavy loading). Kondisi pembebanan ringan ditentukan selama terbang jelajah dengan kecepatan maksimum. Kondisi pembebanan berat ditentukan selama lepas landas dengan kecepatan minimum. Setelah koefisien dorong ditentukan untuk kedua kondisi pembebanan, maka daya yang dibutuhkan untuk menerbangkan pesawat dapat dihitung dengan persamaan (3) dan persamaan (4) sebagai berikut [2], [6].

- Heavy loading, low speed take - off

$$
T c_{t o} \gg 1, \quad \eta_{\text {i to }} \ll 1 P_{\text {shaft to }}=\frac{T_{t o}{ }^{3 / 2}}{(2 \pi \rho)^{1 / 2}} \frac{1}{R} \frac{1}{\eta_{v \text { to }}}
$$

- $\quad$ Light loading, high speed cruise

$$
T c_{c r} \ll 1, \quad \eta_{i c r} \simeq 1 P_{\text {shaft } c r}=T_{c r} V_{c r} \frac{1}{\eta_{v c r}}
$$

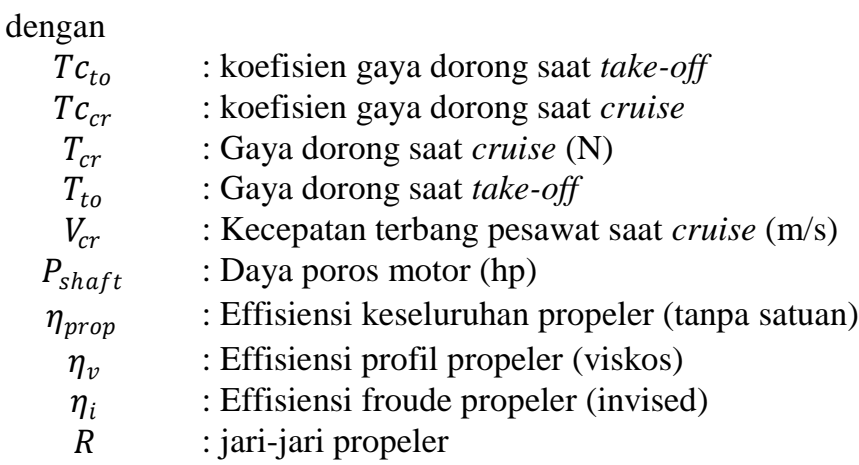

Selanjutnya daya poros dari mesin yang dihubungkan dengan propeler akan menghasilkan thrust (gaya dorong) sehingga pesawat dapat diterbangkan. Pada mesin jet atau piston yang menggunakan propeler, hubungan antara gaya dorong dan daya poros dari mesin dapat didefinisikan melalui perhitungan efisiensi propeler. Efisiensi propeler adalah hasil kali dari efisiensi viskos dan efisiensi invised. Efisiensi viskos menyebabkan hambatan profil viskos pada propeler, sementara efisiensi Froude invised menyebabkan energi kinetik yang hilang dalam percepatan propwash. Perhitungan daya poros melalui efisiensi propeler ditunjukkan dengan persamaan (5) dan persamaan (6) berikut [2], [6].

$$
\begin{gathered}
\frac{T_{c r} V_{c r}}{P_{\text {shaft }}}=\frac{P_{\text {prop }}}{P_{\text {shaft }}}=\eta_{\text {prop }} \\
\eta_{\text {prop }}=\eta_{v} \eta_{i}
\end{gathered}
$$

Langkah-langkah yang dilakukan pada penelitian ini disajikan dalam diagram alir yang ditunjukkan pada Gambar 1. Dibandingkan dengan penelitian-penelitian sebelumnya, pada penelitian ini analisa pemilihan mesin dan propeler dilakukan dengan metode analisa perhitungan tanpa adanya eksperimen atau pengujian. Penentuan kebutuhan daya mesin dihitung pada dua kondisi pembebanan yaitu pembebanan berat untuk pesawat lepas landas dan pembebanan ringan untuk pesawat terbang jelajah. Setelah dilakukan perhitungan kebutuhan daya mesin, selanjutnya dilakukan komparasi terhadap beberapa kandidat mesin yang tersedia dengan kriteria tertentu diantaranya daya yang dihasilkan mesin, berat mesin, dan konsumsi bahan bakar. Mesin yang terpilih selanjutnya menjadi penentu pemilihan propeler yang akan digunakan, yang berpengaruh terhadap gaya dorong yang akan dihasilkan pada rpm tertentu serta daya yang dibutuhkan untuk memutar propeler tersebut. Pemilihan propeler dilakukan berdasarkan analisa perhitungan dengan menggunakan aplikasi kalkulator propeler yang merupakan salah satu metode standar untuk mengoreksi daya (horsepower) dengan menggunakan formula koreksi Dyno yang mengacu pada SAE J1349 yaitu International Standard Certified Power. Dengan menggunakan aplikasi propeler kalkulator, diperoleh perkiraan daya yang dibutuhkan dan gaya dorong yang dihasilkan masing-masing propeler dengan memberikan masukan berupa parameter rpm, diameter dan pitch ke aplikasi kalkulator propeler tersebut. 


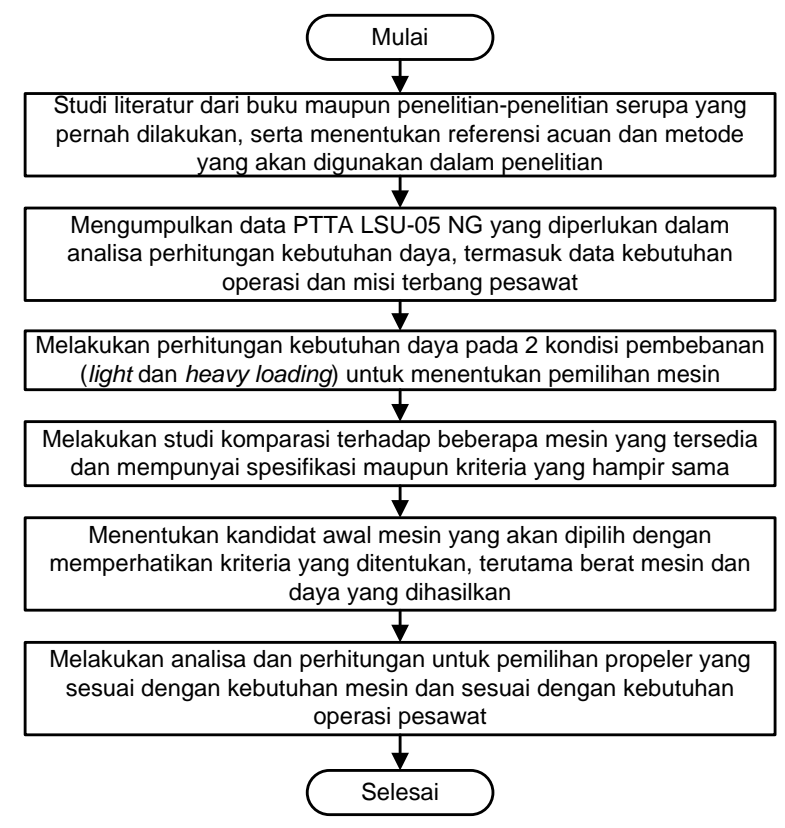

Gambar 1. Diagram alir tahapan penelitian

\section{HASIL DAN PEMBAHASAN}

Pemilihan mesin dan propeler untuk pesawat LSU-05 NG dianalisis berdasarkan perhitungan kebutuhan daya dan gaya dorong pesawat serta efisiensi putaran propeler.

\subsection{Daya Dorong Pesawat}

Besar gaya dorong static setidaknya sebesar sepertiga kali berat total pesawat untuk mendapatkan kemampuan terbang jelajah (cruise) dan terbang menanjak (climb) yang cukup [2], [5]. Untuk menentukan gaya dorong take-off dipilih konstanta 0.47 yang diperoleh dari hasil iterasi sehingga perhitungan gaya dorong take-off dapat ditunjukkan pada persamaan (7) berikut.

$$
T_{t o} \quad=0,47 \times W=391,51 \mathrm{~N}
$$

Daya poros mesin dapat dihitung dengan persamaan yang telah dijelaskan pada bagian metodologi penelitian. Proses perhitungan dibagi menjadi langkah-langkah sebagai berikut [2]:

- Mengasumsikan rasio thrust to weight untuk kedua kondisi pembebanan

- Menghitung gaya dorong dan koefisien dorong untuk kedua kondisi pembebanan.

- Mengasumsikan efisiensi total baling-baling dari literature [7] kemudian menghitung efisiensi viskos.

- Menghitung daya poros mesin untuk kedua kondisi pembebanan.

Selanjutnya, kebutuhan daya dorong pesawat yang dihitung berdasarkan dua kondisi pembebanan dengan mengacu pada persamaan (1) hingga persamaan (7) dapat ditunjukkan pada

Tabel 2.

Tabel 2. Hasil perhitungan kebutuhan daya dorong

\begin{tabular}{lcc}
\hline Parameter & Nilai & Unit \\
\hline Koefisien Thrust (Tc) saat Take-Off & 1,0 & \\
Koefisien Thrust (Tc) saat Cruise & 0,5 & \\
Efisiensi Propeler & 0,85 & \\
Efisiensi viskos saat Take-Off & 0,6375 & \\
Efisiensi viskos saat Cruise & 0,85 & \\
Gaya Dorong (T) saat Take-Off & 391,5 & $\mathrm{~N}$ \\
Gaya Dorong (T) saat Cruise & 181 & $\mathrm{~N}$ \\
Massa Jenis Udara (sea level) & 1,225 & $\mathrm{~kg} / \mathrm{m}^{3}$ \\
Kecepatan Cruise & $40(77,7)$ & $\mathrm{m} / \mathrm{s}(\mathrm{kts})$ \\
Output & & \\
Daya pada kondisi Heavy Loading & 12.320 & $\mathrm{Watt}$ \\
& 16,5 & $\mathrm{hp}$ \\
Daya pada kondisi Light Loading & 8.520 & $\mathrm{Watt}$ \\
\end{tabular}


Berdasarkan data hasil perhitungan kebutuhan daya dorong pada

Tabel 2, diperoleh bahwa daya yang dibutuhkan pada kondisi pembebanan berat adalah 16.5 hp dan untuk pembebanan ringan adalah 11,4 hp. Jadi dapat disimpulkan PTTA LSU-05 NG membutuhkan mesin yang dapat menyuplai daya minimal sebesar $16.5 \mathrm{hp}$. Pada

Tabel 2 nilai koefisien thrust saat take-off menunjukkan nilai paling minimal dari persyaratan koefisien thrust itu sendiri yaitu sebesar 1 . Hal ini menandakan kebutuhan daya minimal yang diperlukan untuk take-off dengan mengacu pada persamaan (1) dimana besarnya koefisien thrust sebanding dengan gaya dorong dan mengacu pada persamaan (3) dimana gaya dorong itu sendiri sebanding dengan daya yang dibutuhkan. Sehingga dengan nilai koefisien thrust paling minimal didapatkan minimal daya yang dibutuhkan untuk take-off dalam hal ini sebesar $16.5 \mathrm{hp}$. Selanjutnya dilakukan studi komparasi untuk spesifikasi beberapa mesin yang tersedia guna mendapatkan rekomendasi mesin yang sesuai untuk kebutuhan pesawat LSU-05 NG.

\subsection{Kriteria Pemilihan Mesin LSU-05 NG}

Terdapat kriteria-kriteria yang diperhatikan agar pemilihan mesin LSU-05 NG tepat dan efisien sesuai dengan DRO yang telah dirancang. Kriteria-kriteria tersebut antara lain:

1. Gaya dorong yang dibutuhkan.

Kebutuhan gaya dorong pesawat dihitung pada saat pesawat lepas landas (take off), dan saat pesawat melakukan terbang jelajah (cruise). Gaya dorong yang dihasilkan mesin sangat bergantung pada dimensi dari propeler. Mesin yang terpilih harus memenuhi kebutuhan minimum gaya dorong yang diperlukan dengan kombinasi dari propeler yang digunakan. Kebutuhan gaya dorong pesawat LSU-05 NG saat take off yaitu 391,51 N, serta kebutuhan gaya dorong saat pesawat melakukan terbang jelajah (cruise) yaitu 181,05 N.

2. Daya putar atau daya poros (shaft power) yang dihasilkan oleh mesin piston untuk memutar propeler. Telah dilakukan perhitungan daya yang diperlukan untuk memutar propeler hingga mencapai kecepatan putar maksimum. Daya maksimum yang diperlukan pada kondisi pembebanan berat adalah 16,52 hp, sedangkan daya yang diperlukam pada kondisi pembebanan ringan adalah 11,42 hp.

3. Berat total komponen mesin

Pada persyaratan DRO pesawat LSU-05 NG, berat maksimum yang dialokasikan untuk mesin sebesar 5 $\mathrm{kg}$. Berat komponen sangat berpengaruh pada performa terbang pesawat nirawak. Hal ini dikarenakan jika terdapat komponen yang terlalu berat dan posisi peletakannya tidak tepat maka dapat mempengaruhi kestabilan pesawat tersebut.

Melihat dari berbagai pertimbangan antara lain perhitungan berat pesawat yang akan dirancang, studi perbandingan dengan pesawat-pesawat yang memiliki berat hampir sama maupun penentuan konfigurasi umum, maka untuk mendapatkan thrust yang sesuai dipilih mesin piston ber-propeler sebagai sistem propulsi. Selanjutnya dilakukan studi komparasi terhadap beberapa mesin yang tersedia serta mempunyai spesifikasi maupun kriteria yang hampir sama. Berikut tabel perbandingan antara lima mesin yang tersedia [9]-[13].

\begin{tabular}{|c|c|c|c|c|c|}
\hline Name/Part Code & MVVS 116 IRS & Evolution 116GX2 & DA-150 & DA-170 & DLE-170 \\
\hline Manufacture & MVVS Engine & Evolution Engine & Dessert Aircraft & Dessert Aircraft & $\begin{array}{l}\text { Mile Hao Chiang } \\
\text { Chinese }\end{array}$ \\
\hline Type & \multicolumn{5}{|c|}{2 Stroke Gas Engine, Twin Cylinder } \\
\hline Display & & & & 170 & \\
\hline Displacment & $116 \mathrm{cc}$ & $116 \mathrm{cc}$ & $150 \mathrm{cc}$ & $171.8 \mathrm{cc}$ & $170 \mathrm{cc}$ \\
\hline Bore & $42 \mathrm{~mm}$ & $42 \mathrm{~mm}$ & 1.9219in & $52 \mathrm{~mm}$ & $52 \mathrm{~mm}$ \\
\hline Stroke & $42 \mathrm{~mm}$ & $42 \mathrm{~mm}$ & 1.5478in & $40.49 \mathrm{~mm}$ & $40 \mathrm{~mm}$ \\
\hline Total Weight & $3.37 \mathrm{~kg}$ & $3.37 \mathrm{~kg}$ & $3.76 \mathrm{~kg}$ & $3.56 \mathrm{~kg}$ & $4.11 \mathrm{~kg}$ \\
\hline \multirow[t]{3}{*}{ Output (Maxpower) } & $14 \mathrm{hp}$ & $14 \mathrm{hp}$ & $16.5 \mathrm{hp}$ & $17.3 \mathrm{hp}$ & $17.5 \mathrm{hp}$ \\
\hline & @ 6400 rpm & @ 6400 rpm & @ 6500rpm & @ 9000 rpm & @ 9000 rpm \\
\hline & & \multicolumn{2}{|c|}{ Propeler } & & \\
\hline 2 Blade & $\begin{array}{c}28 \times 10-14,30 \times 10- \\
12,32 \times 10\end{array}$ & $\begin{array}{c}28 \times 10-14,30 \times 10- \\
12,32 \times 10\end{array}$ & $\begin{array}{c}30 \times 10-12,32 \times 10- \\
12\end{array}$ & $\begin{array}{l}30 \times 13,31 \times 12 \\
32 \times 11-12\end{array}$ & $30 \times 12,32 \times 10$ \\
\hline
\end{tabular}




$\begin{array}{lccccc}3 \text { Blade } & 25 \times 12,26 \times 12 & - & 28.5,29 \times 12 & 28.5 \times 12,29.12 & - \\ \text { Speed Range (RPM) } & 1000-7500 & 1000-7500 & 1000-6500 & 1100-6500 & 1100-7500 \\ \text { Fuel Consumption } & - & - & 3.30 z / m i n @ 6000 \mathrm{r} & 7,1 \text { L/H @ 6,000 } & 4 \mathrm{~L} / \mathrm{H} @ 6000 \text { RPM } \\ & & & \mathrm{pm} & \text { RPM } & \\ \text { Price (Engine Only) } & \text { USD 1336.90 } & \text { USD 1499 } & \text { USD 1350 } & \text { USD 1695 } & \text { USD 1049.99 }\end{array}$

Dari hasil analisis pemilihan mesin pesawat LSU-05 NG, maka dapat disimpulkan secara spesifik berdasarkan data-data mesin dan kriteria-kriteria pemilihan mesin diatas sampai dengan tahap perancangan konsep, diperoleh tiga kandidat mesin yang dipilih yaitu DA-150, DA-170, dan DLE 170. Dari ketiga mesin tersebut DA-170 memiliki kapasitas paling besar yaitu $171.8 \mathrm{cc}$ dengan konsumsi bahan bakar juga paling besar. Mesin DA-150 memiliki kapasitas paling kecil yaitu $150 \mathrm{cc}$ namun konsumsi bahan bakar lebih besar dibandingkan DLE 170. Selain itu, dari ketiga mesin tersebut DLE 170 menghasilkan daya yang paling besar dibandingkan dua mesin lainnya dengan rentang rpm lebih besar pula. Ketiga mesin memiliki berat yang masih dapat diakomodir oleh persyaratan pesawat yaitu maksimal $5 \mathrm{~kg}$ berat yang dialokasikan untuk mesin. Dengan mempertimbangkan kriteria kapasitas mesin, konsumsi bahan bakar, daya yang dihasilkan, dan rentang rpm dari ketiga mesin tersebut diperoleh prioritas utama kandidat mesin yang dipilih yaitu DLE 170 sementara kedua mesin lainnya yaitu DA 150 dan DA 170 menjadi alternatif pilihan setelah DLE 170. Selanjutnya, sesuai dengan spesifikasi mesin tersebut maka perlu dilakukan analisa pemilihan propeler atau matching propeller yang akan digunakan.

\subsection{Analisis Pemilihan Propeler}

Gaya dorong atau thrust mesin adalah hasil dari perputaran propeler yang mengubah daya perputaran mesin menjadi gaya dorong. Selama pesawat tidak bergerak, propeler beroperasi dalam kondisi statik. Tidak ada aliran udara masuk menuju propeler, melainkan propeler yang membuat gerakan arus masuk sendiri. Propeler memiliki koefisien gaya dorong yang merupakan perbandingan maksimum gaya dorong yang dihasilkan oleh mesin pesawat terhadap berat total pesawat. Pada pesawat berawak dan tak berawak pada umumnya perbandingan gaya dorong terhadap beban berdasarkan dari aturan pengalaman para desainer pesawat. Referensi ini diperoleh dari hasil desain pesawat sebelumnya. Kesepakatan tersebut menyatakan bahwa gaya dorong statik mampu membawa pesawat hingga kondisi jelajah (cruise) dan menanjak (climb) pada minimal satu banding tiga (1/3) total berat pesawat [2], [6]. Persamaan teoritik gaya dorong statik ditunjukkan pada persamaan (8) [5].

$$
F=1.225 \frac{\pi(0.0254 \cdot d)^{2}}{4}\left(R P M_{\text {prop }} \cdot 0.0254 \cdot \text { pitch } \cdot \frac{1 \mathrm{~min}}{60 \mathrm{~s}}\right)^{2}
$$

Dari perumusan teoritik persamaan (8), diketahui bahwa gaya dorong yang dihasilkan mesin dapat dirumuskan dengan mengetahui berapa rpm, pitch, dan diameter propeler. Gaya dorong dirumuskan sebagai kuadrat dari rpm, diameter, dan pitch propeler. Perhitungan gaya dorong secara teoritis diperoleh dengan menggunakan aplikasi kalkulator propeler sebagaimana yang ditunjukkan pada Error! Reference source not found.. Pada aplikasi ini, jenis dan ukuran propeler sudah diperhitungkan dengan nilai konstan propeler yang diperoleh berdasarkan pengujian lapangan dan laboratorium. Seperti terlihat pada Error! Reference source not found., aplikasi kalkulator propeler ini merupakan salah satu metode standar untuk mengoreksi daya (horsepower) dengan menggunakan formula koreksi Dyno yang mengacu pada SAE J1349 yaitu International Standard Certified Power. Dengan menggunakan aplikasi propeler kalkulator, diperoleh perkiraan daya dan gaya dorong yang dihasilkan masing-masing propeler dengan memberikan masukan berupa parameter rpm, diameter dan pitch ke aplikasi kalkulator propeler tersebut.

Selanjutnya dilakukan perbandingan besarnya gaya dorong yang dihasilkan oleh propeler 2 bilah dengan ukuran $30 \times 12,32$ × 10, dan 32 × 12 pada maksimum rpm yaitu sebesar 8000. Grafik yang diperoleh dari hasil perhitungan aplikasi kalkulator propeler ditunjukkan pada Gambar 3 dan Gambar 4. Hasil dari grafik pada Gambar 3 menunjukkan bahwa pada rpm yang sama, daya yang dibutuhkan untuk memutar propeler sebanding dengan ukuran propeler. Semakin besar ukuran propeler, maka semakin besar pula daya yang dibutuhkan untuk menggerakannya. Untuk propeler dimensi $32 \times 12$ pada $6500 \mathrm{rpm}$, daya yang dibutuhkan melebihi daya mesin, yaitu mencapai $19,14 \mathrm{hp}$ sementara pada $7000 \mathrm{rpm}$, kebutuhan daya ketiga propeler melebihi daya mesin. 


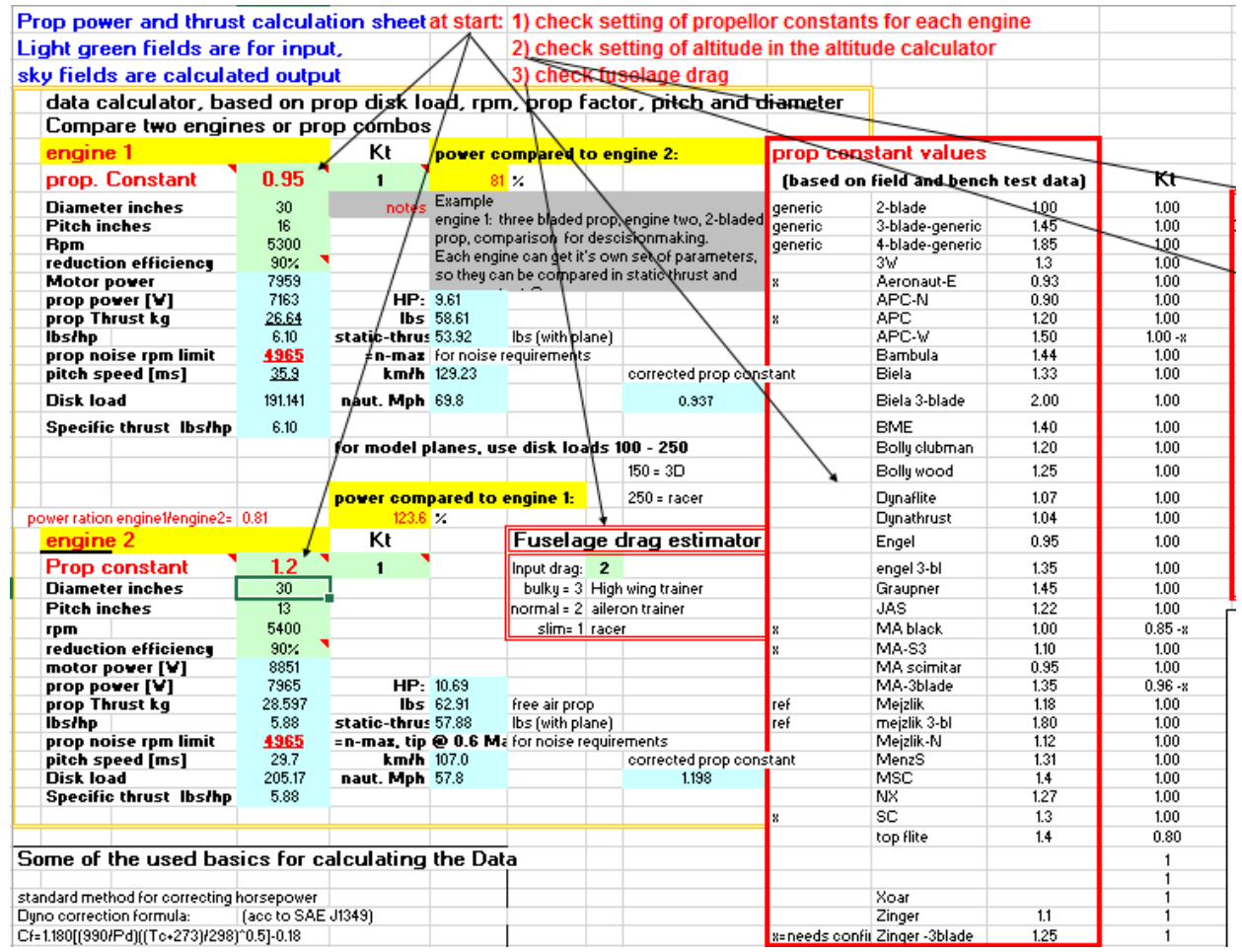

Gambar 2. Aplikasi kalkulator propeler [7]

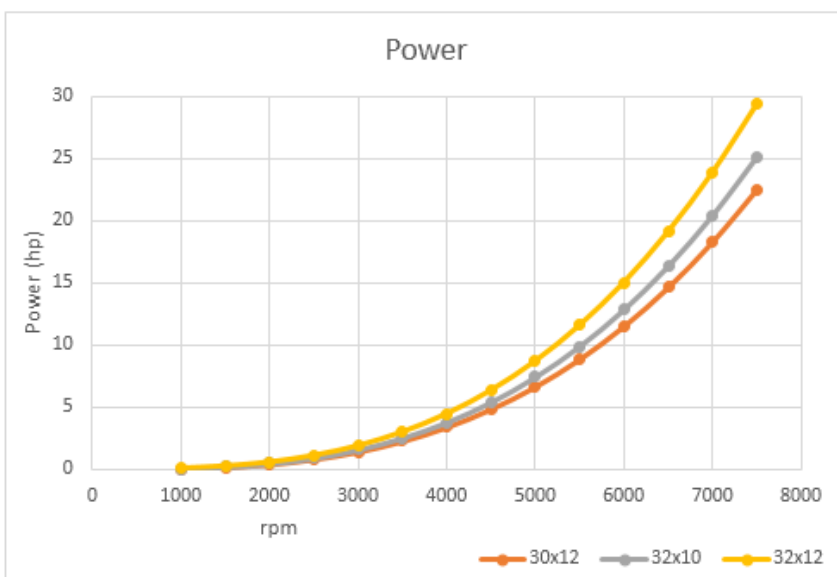

Gambar 3. Pengaruh ukuran propeler dan rpm terhadap kebutuhan daya

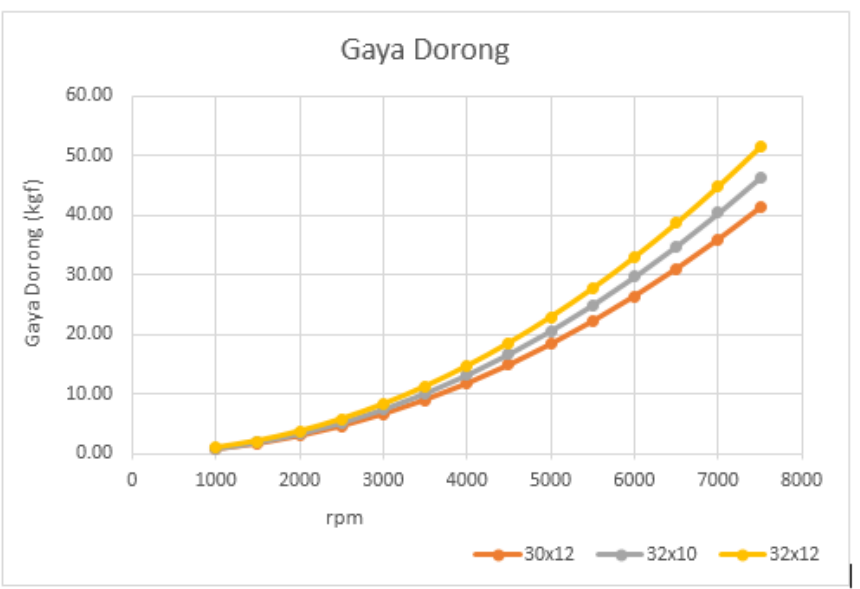

Gambar 4. Pengaruh ukuran propeler dan rpm terhadap gaya dorong yang dihasilkan 
Hasil dari grafik pada Gambar 4 menunjukkan bahwa pada rpm rendah, mulai dari 1000 hingga 3500, perbedaan gaya dorong antara ketiga propeler tidak terlalu signifikan. Namun untuk rpm diatas 3500 terdapat perbedaan cukup signifikan dikarenakan gaya dorong merupakan fungsi kuadrat dari rpm. Grafik pada Gambar 4 juga menunjukkan bahwa pada rpm yang sama, nilai gaya dorong sebanding dengan ukuran propeler dimana semakin besar ukuran propeler maka semakin besar pula gaya dorong yang dihasilkan. Hal ini sesuai dengan persamaan 8 bahwa gaya dorong sebanding dengan kuadrat nilai pitch dan diameter dari propeler. Gaya dorong statik setidaknya sebesar sepertiga kali berat total pesawat (minimal 28,5 kgf) untuk mendapatkan kemampuan terbang jelajah (cruise) dan terbang menanjak (climb) yang cukup. Pada rpm 6500 propeler dimensi 30x12 dan 32x10 masing-masing menghasilkan gaya dorong hingga $31 \mathrm{KgF}$ dan $34,8 \mathrm{KgF}$. Propeler 32x10 dan 32x12 pada rpm 6000 masing-masing menghasilkan gaya dorong sebesar 29.67 KgF dan $32.93 \mathrm{kgf}$. Untuk mengoptimalkan daya mesin yang tersedia dan menghasilkan gaya dorong yang maksimal, maka propeler yang direkomendasikan adalah propeler berdimensi 32x10.

\section{KESIMPULAN}

Analisa perhitungan kebutuhan daya pada kondisi pembebanan berat dan pembebanan ringan serta analisa perhitungan propeler telah dilakukan. Hasil analisa perhitungan tersebut telah digunakan untuk menentukan mesin dan propeler yang sesuai untuk pesawat LSU-05 NG. Berdasarkan hasil analisa pemilihan mesin dan propeler serta memperhatikan kriteria-kriteria kebutuhan pesawat LSU-05 NG, diperoleh rekomendasi mesin yang digunakan memiliki daya minimal $16.5 \mathrm{hp}$ dengan kandidat utama mesin DLE 170 dan propeler dengan dimensi 32x10. Selanjutnya, sebagai tindak lanjut dari penelitian ini diperlukan adanya pengujian terhadap ketiga mesin dan propeler untuk mengetahui gaya dorong yang dihasilkan serta konsumsi bahan bakar pada beberapa kondisi rpm sebagai pertimbangan pemilihan mesin dan propeler.

\section{DAFTAR PUSTAKA}

[1] A. Rizaldi, "LSU-05 NG Design Requirements and Objectives," Bogor, Indonesia, 2019.

[2] D. Anggraeni, A. R. Sumaryanto, E. Sumarna, and A. Rahmadi, "Engine and Propeller Selection for Propulsion System LAPAN Surveillance UAV - 05 (LSU-05) Using Analytic and Experimental Test," in International Seminar of Aerospace Science and Technology II, 2014, pp. 41-50.

[3] A. Balachandran, A. Shah, and D. J. Challa, "Propulsion Selection and Analysis for Unmanned Aerial Vehicles for SAE Aero Design Series," Int. J. Eng. Sci., vol. 3, no. 8, pp. 29-35, 2014.

[4] A. Dinç, "Sizing of a turboprop unmanned air vehicle and its propulsion system," Isi Bilim. Ve Tek. Dergisi/ J. Therm. Sci. Technol., 2015.

[5] I. T. Setyadewi and Y. A. Nugroho, "ANALISIS PEMILIHAN PROPELLER MESIN PESAWAT TANPA AWAK LSU 03,” Majalah Sains dan Teknologi Dirgantara, pp. 23-30, 2018.

[6] "Flight Thrust, Power, and Energy Relations," 2009. [Online]. Available: https://web.mit.edu/16.unified/www/SPRING/systems/Lab_Notes/airpower.pdf.

[7] "Propeller Power Calculator." [Online]. Available: http://www.mini-iac.no/wpcontent/uploads/2012/11/prop-power-calculator-Neu-2230-1Y_15s_-Mejzlik.xls.

[8] N. Atmasari et al., "ANALISIS PENENTUAN POWER LOADING PADA DESAIN AWAL PESAWAT TERBANG TANPA AWAK LSU-05 NG,” J. Teknol. Dirgant., vol. 17, pp. 109-122, 2019.

[9] Dessert Aircraft Australia, DA 150 Owners Manual. Australia.

[10] Dessert Aircraft Australia, DA 170 Owners Manual. Australia.

[11] DLE Hobbico, DLE 170 Operator's Manual. 2010.

[12] MVVS, Operating Instructions MVVS 116 IRS No : 3010. Czech Republic.

[13] Evolution gas Power Horizon Hobby, Evolution Engines 116GX2 User Guide. 2007. 